\title{
The Efficiency of Regional Innovation Systems in New Member States of the European Union: A Nonparametric DEA Approach
}

\author{
Giedre Dzemydaite ${ }^{1}$, Ignas Dzemyda ${ }^{2}$, Birute Galiniene ${ }^{3}$
}

1,3 Vilnius University, ${ }^{2}$ Vilnius Gediminas Technical University

\begin{abstract}
This paper evaluates the Eastern and Central EU regions according to the efficiency level of innovation systems by application of nonparametric data envelopment analysis (DEA). The most technologically inefficient NUTS2 regions of Central and Eastern EU are identified. The governmental institutions in these regions should enforce a higher level of regional innovative activity, as regional potential to create a higher value to the economy with current resources has not been reached yet.
\end{abstract}

Keywords - Data envelopment analysis, innovation systems, regional efficiency.

\section{INTRODUCTION}

Regional disparities remain a significant issue in the fields of economic development, creation and commercialisation of innovative products, social aspects between the European Union regions and countries (Burda \& Severgnini, 2009; ESPON, 2012; Okubo, 2012; Dzemydaite et al. 2015). As stated in "Europe2020" growth strategy, the member states have to find ways to strengthen their growth potential by expanding innovative activities and improving productivity by creating products with higher value added and creating better jobs in the economy (European Commission, 2013).

More innovative and efficient production technology attracts new investments to economically more developed countries and regions. This remains the key to further economic development and successful worldwide competition of the EU regions (COM(2004) 107). Thus, high efficiency level of production technology and globally competitive products make the significant impact on future growth opportunities and attractiveness of the region.

Regional innovation systems are an alliance of private and public interests, governmental institutions, enterprises and other organisations (Cooke, 1992, 2004; Asheim \& Gertler, 2005; Doloreux, 2003), where the cooperation itself defines the geographical dimensions of the system, not administrative boundaries. Regional innovation systems are believed to be the cause for the increased competitiveness and productivity in the region (Anderson, 2013). The concrete contributions to increase competitiveness and productivity become the source of an innovation system (Anderson, 2013). There is a large set of recent analysis of regional innovation systems, their main components and driving factors (Broekel, 2012; Autant-Bernard \& LeSage, 2011; Cai \& Hanley, 2014; Bosco \& Brugnoli, 2010; Fritsch \& Slavtchev, 2011). Innovative factors and regional innovation system efficiency are important for enforcing economic development (De Bruijn \& Lagendijk, 2005).
The novelty of the present research is that new insights are given about regional innovation systems of Central and Eastern EU regions that are still comparatively lagging in the creation and commercialisation of innovative products and in the efficient usage of current resources, human capital and investments. Overall 40 regions were analysed and compared in this research to find out weak points and possible direction for further improvements of regional innovation systems. Nonparametric method of data envelopment analysis (DEA) was used in the paper to compare efficiency and production technologies of innovation systems. The latest available regional data of 2013 were used in the research (Eurostat database, 2015).

\section{EFFICIENCY OF REgional INNOVATION Systems: Theoretical Aspects}

Changes of economic circumstances require deep understanding of issues of rising efficiency of regional innovation systems. One of the main challenges of regions is how to develop economic activities to create high value added products competitive in the global business environment. Nonparametric mathematical programming methods are commonly used to expand the application of production functioning. Some researchers try to evaluate the efficiency of region innovation systems by analysing the production function of knowledge creation, which relates the inputs and outputs in one model (D'Agostino et al., 2013). The research of technical region efficiency reflects whether a region achieves the desired innovative result with a human capital, investments in new technologies and other resources.

For example, Lafarga and Balderrama (2015) measured the relative technical efficiency of Mexico's regional innovation systems, as defined by its 32 states. The results led to the conclusion of the non-existence of a positive relation between the number of resources of an innovation system and its productivity efficiency.

Autant-Bernard and LeSage (2011) examined the knowledge spillover between different French regions by application of nonparametric methods, as well as estimated a knowledge production function. It was evaluated that the largest indirect and direct effects were produced by private research activities that spilled across industry boundaries.

Broekel et al. (2010) evaluated the relationship between cooperation and successful innovative activity in the German regions. Non-convex order-m frontier method was applied. The research revealed a positive relationship between regional innovation system efficiency and regional cooperation level. This case revealed that the German regions with average regional and inter-regional cooperation intensities were found to outperform 
those characterised by extremely low, high or unbalanced cooperation behaviour.

Zhong et al. (2011) examined the efficiency of regional investment for research and technology spillovers in China. The research results reflected that a more diversified regional policy should be formed in order to achieve effective creation process of innovation in different country regions. Chen and Guan (2012) applied nonparametric methods to reflect that there were some serious inconsistencies between technology capability and economic performance in most Chinese RISs. The authors (Chen \& Guan, 2012) found that intensive investment in science and technology, although necessary for catching up with highly developed countries, did not necessarily bring high efficiency of the RIS and could not guarantee success in innovation. Substantial inconsistencies exist between technological development capacity and commercialisation capacity in most regional innovation systems, and this downstream commercialisation capacity plays a more important role in the innovation performance of regional innovation systems. Kaihua and Mingting (2014) indicated that the embedded and contextualised policy-oriented environment did not effectively suit China's regional innovation systems. Bai (2013) represented that the government subsidies, interplays between enterprises and universities, and degree of participation by enterprises had positive effects on various degrees of innovation efficiency in the eastern region of China, but significantly a negative impact in the western region. These findings suggest that there is no universal policy to raise efficiency of regional innovation systems.

Yi and Fengyan (2015) performed the analysis based on the 31 provinces and the cities' unbalanced panel data. The findings showed that innovation performance of RISs in different provinces and cities differed greatly and that there were various factors affecting regional innovation performance. Yi and Fengyan (2015) emphasised that enterprise technology input and government investments had a negative impact on the regional innovation performance.

Cai and Hanley (2014) made a rating of world countries by evaluating technical efficiency of creating innovations. The research reflected that developed countries, which had a number of potential resources for creating innovation, such as the USA, Great Britain, and Austria, used the resources not efficiently enough. Developing countries such as China and India and a developed country Switzerland were more efficient.

Bosco and Brugnoli (2010), Fritsh and Slavchev (2011) examined the factors that destined the efficiency of region innovative systems and regional differences applying the function of knowledge creation and production, as well as methods of nonparametric mathematical programming Research by Bosco and Brugnoli (2010), Fritsh and Slavchev (2011) proved a positive connection between region innovative system efficiency and productivity. It was evaluated that different factors exerted different influence on innovation creation in different countries and regions.

Since technological progress is a significant indicator of increasing labour productivity, it is necessary to assess the factors that affect the growth of different parameters of technological progress (Svetikas \& Dzemyda, 2009). In this process, universities are more concerned to enforce cooperation with business enterprises as it is a new field of their fund supplementation (Dzemyda \& Karčiauskas, 2012a, 2012b; Drăgan, Dzemyda \& Karčiauskas, 2011).

Fritsch and Slavtchev (2011) suggest that regional innovation system performance is strongly influenced by the level and quality of interaction and exchange between its different elements. Tharakan (2015) demonstrates the value of indigenous knowledge systems that have developed within various societies independent of, and prior to, the advent of the modern scientific knowledge system.

Moodysson and Zukauskaite (2014) reveal that regional policy-makers' possibilities to influence firm networks seem to be limited. The analysis of Makkonen and Inkinen (2014) indicates that policy documents treat clusters and innovation systems mainly as isolated islands that ignore spatial scaling and complexity.

A number of previous studies reveal an importance to evaluate not only the level of available innovative resources in the region but also to measure how these resources are used to generate high value added products in different regions, as well as to identify the main factors forming regional economic results even with the comparable level of inputs between regions.

\section{Data Envelopment Analysis for the Evaluation} of Regional InNovation System EfFiciency

To evaluate the efficiency level of regional innovation systems, it is important to detect how far their regional production technology is from the efficient frontier. This position is found comparing different regions' performance involved in the analysis. In the first step, the most efficient regions of the group are detected. Then performance of other regions is compared to the most efficient regions.

40 regions were selected for the analysis from the Eastern and Central EU that joined the EU in 2004. These regions have similarities according to the development level of their innovation systems. According to the EU Innovation Scoreboard, they are considered moderate or modest innovators (European Commission, 2014). All the evaluations were made according to the group of regions involved in the analysis. Evaluated regional levels of efficiency are conditional based on the comparisons of regions involved in the analysis. The latest available regional data of 2013 and 2013 were used from the Eurostat database (2015).

For the evaluation of technical efficiency, a data envelopment analysis method (DEA) was applied, which helped estimate regions' positioning according to efficient frontier. This method is nonparametric and helps expand the analysis of regional production function (Daraio \& Simar, 2007a; Dzemydaitė \& Galinienè, 2013). In the recent research, the nonparametric methods have been applied to evaluate the EU regional policy and its efficiency (Dzemydaitė \& Galinienè, 2013; Dzemydaite et al., 2015).

\section{A. The Method of Data Envelopment Analysis}

The method of data envelopment analysis was set in detailed formulas by Daraio and Simar (2007a). In the first step of application of this method, it is stated that every region involved in the analysis disposes a set of inputs $x \in R_{+}^{p}$ that produce a set of 
outputs $y \in R_{+}^{q}$. Input and output indicators are positive numbers All possible combinations of inputs and outputs $(x, y)$ are defined as (Schaffer et al., 2011):

$$
\psi=\left\{(x, y) \in r_{+}^{p+q} \mid x \_ \text {can_produce } y \mid\right\} .
$$

The margin of $\psi$ reflects maximum output that can be generated with given inputs. Efficient frontier is defined as:

$$
Y^{\delta}=\left\{\left(x, y^{\delta}(x)\right) \mid y^{\delta}(x) \in Y(x): \lambda y^{\delta}(x) \notin Y(x), \forall \lambda>1\right\} .
$$

$Y(x)$ is a set of technologically feasible outputs. $y^{\delta}(x)$ is a maximum achievable output with input level $x$. Efficiency score of a region $\lambda(x, y)$ is defined as:

$$
\lambda(x, y)=\sup \{\lambda \mid(x, \lambda y) \in \psi\}=\sup \{\lambda \mid \lambda y \in Y(x)\} .
$$

To determine $\psi$, nonparametric estimators, such as method of the data envelopment analysis (DEA), could be applied. This method helps evaluate an efficient line that reflects the highest technically possible level of production of a chosen group of the regions (Schaffer et al., 2011).

\section{B. Input and Output Indicators for Evaluation of Innovation System Efficiency}

The main indicators for the evaluation of regional innovation system efficiency were selected according to the available regional datasets and according to the latest research of regional innovation systems. Two outputs were selected and evaluated in the first stage of the research: $y_{1}$ - gross domestic product in purchasing power parity per inhabitant; $y_{2}-$ a number of patents per inhabitant. $y_{1}$ is commonly used as the output of the overall regional economy and $y_{2}$ is commonly applied as the output of regional innovation systems (for example, Bosco \& Brugnoli 2010; Fritsch \& Slavtchev, 2011; Dzemydaite et al., 2015). The latest regional data of indicators from Eurostat database were used in the research, i.e. GDP - for 2013 and the number of patent applications - for 2012 (Eurostat database, 2015). Therefore, indicators were selected on the basis of the date of output indicators.

Three input indicators were selected that were mostly related to human capital characteristics and investments to the regions: $x_{1}$ - the intramural cumulative expenditures for research and development (R\&D) in purchasing power standard per inhabitant, $x_{2}$ - human resources in science and technology calculated as a number of persons with tertiary education (ISCED) and/ or employed in science and technology, as percentage of total population, $x_{3}$ - human capital employed in high technology and knowledge-intensive sectors, the percentage of total employment. It was selected to analyse cumulative expenditures on research and development of 5 previous years. It is based on the assumption that it takes time lag for expenditures to give feasible results to the economy, so the results should be seen not in the current year but in the following years.

Data were analysed according to the European Union nomenclature of territorial units. The second regional level (NUTS2) was selected that consisted of similar size regions that had from 800 thousand to 3 million inhabitants. The European Union cohesion policy is formed according to this regional level (European Commission, 2004). The Eastern and Central European Union regions of the countries that joined the EU in 2004 were analysed. Regions of Estonia, Latvia, Lithuania, Poland, Slovenia, Slovakia, Hungary and the Czech Republic were analysed. In total, 40 regions of NUTS2 level were analysed.

Such countries as Lithuania, Latvia, Estonia, have comparatively small number of inhabitants. These countries are considered one region, while such countries as Poland are divided in smaller territories according to the EU territorial classification. Overall, Slovenia is divided in 2 regions, Slovakia into 4, Hungary into 7, the Czech Republic into 8 and Poland into 16 NUTS2 level regions (Eurostat, 2015).

This territory of Eastern and Central Europe was selected to be analysed as it had comparatively common experience with the implementation of EU cohesion policy and possibilities of EU structural funding.

In order to select the most feasible indicators for the data envelopment analysis, the Pearson correlation coefficient was evaluated. For the data analysed, the input indicators significantly correlated with the output indicator - GDP per capita at 0.01 level of confidence (2-tailed) (Table I). There was strong correlation with all the input indicators $x_{1} x_{2}$ and $x_{3}$. Therefore, all three input indicators were involved in the further analysis.

TABLE I

The Correlation Rate of a GDP $\left(Y_{1}\right)$ and Input Indicators

\begin{tabular}{|l|c|c|c|c|}
\hline \multicolumn{1}{|c|}{ Indicators } & $\begin{array}{c}\text { The intramural } \\
\text { cumulative R\&D } \\
\text { expenditures }\left(\boldsymbol{x}_{1}\right)\end{array}$ & $\begin{array}{c}\text { Human resources } \\
\text { in science } \\
\text { and technology }\left(\boldsymbol{x}_{2}\right)\end{array}$ & $\begin{array}{c}\text { Human capital employed } \\
\text { in high technology and } \\
\text { knowledge-intensive sectors }\left(\boldsymbol{x}_{3}\right)\end{array}$ & $\begin{array}{c}\text { Number } \\
\text { of patents } \\
\left(\boldsymbol{y}_{2}\right)\end{array}$ \\
\hline Pearson's correlation rate & 0.847 & 0.865 & 0.794 & 0.384 \\
\hline Significance $(p$ value equals 0.01$)$ & 0.000 & 0.000 & 0.000 & 0.015 \\
\hline
\end{tabular}

Evaluated by the authors according to Eurostat data (2015)

TABLE II

The Correlation Rate of a Number of Patents $\left(Y_{2}\right)$ and Input Indicators

\begin{tabular}{|l|c|c|c|}
\hline \multicolumn{1}{|c|}{ Indicators } & $\begin{array}{c}\text { The intramural cumulative } \\
\text { R\&D expenditures }\left(\boldsymbol{x}_{\mathbf{1}}\right)\end{array}$ & $\begin{array}{c}\text { Human resources in science } \\
\text { and technology }\left(\boldsymbol{x}_{\mathbf{2}}\right)\end{array}$ & $\begin{array}{c}\text { Human capital employed in high technolo- } \\
\text { gy and knowledge-intensive sectors }\left(\boldsymbol{x}_{\mathbf{3}}\right)\end{array}$ \\
\hline Pearson's correlation rate & 0.579 & 0.420 & 0.384 \\
\hline Significance $(p$ value equals 0.01$)$ & 0.000 & 0.007 & 0.015 \\
\hline
\end{tabular}

Evaluated by the authors according to Eurostat data (2015) 
TABLE III

Regions in Central and Eastern Europe with Highest Input and Output Indicators (2013)

\begin{tabular}{|c|c|c|c|c|c|c|c|}
\hline \multicolumn{4}{|c|}{ TOP10 regions according to values of $y_{1}$} & \multicolumn{4}{|c|}{ TOP10 regions according to values of $x_{1}$} \\
\hline No. & Region & Country & $y_{1}$ & No. & Region & Country & $x_{1}$ \\
\hline 1 & SK01 - Bratislavský & Slovakia & 49000 & 1 & CZ01 - Praha & The Czech Republic & 5040.0 \\
\hline 2 & CZ01 - Praha & The Czech Republic & 46000 & 2 & SI02 - Zahodna & Slovenia & 3360.5 \\
\hline 3 & HU10 - Közép-Magyarország & Hungary & 28700 & 3 & SK01 - Bratislavský & Slovakia & 2589.1 \\
\hline 4 & PL12-Mazowieckie & Poland & 28500 & 4 & HU10 - Közép-Magyarország & \begin{tabular}{|l|} 
Hungary \\
\end{tabular} & 2062.8 \\
\hline 5 & SI02 - Zahodna & Slovenia & 25900 & 5 & CZ06-Jihovýchod & Czech & 1733.8 \\
\hline 6 & CZ06-Jihovýchod & Czech & 20600 & 6 & PL12-Mazowieckie & Poland & 1626.1 \\
\hline 7 & PL51 - Dolnoslaskie & Poland & 20100 & 7 & EE00-Eesti & Estonia & 1511.5 \\
\hline 8 & CZ02 - Strední Cechy & The Czech Republic & 19500 & 8 & CZ02-Strední Cechy & The Czech Republic & 1303.8 \\
\hline 9 & EE00-Eesti & Estonia & 19500 & 9 & SI01 - Vzhodna & Slovenia & 1287.5 \\
\hline 10 & LT00 - Lietuva & Lithuania & 19400 & 10 & CZ03-Jihozápad & The Czech Republic & 1080.7 \\
\hline \multicolumn{4}{|c|}{ TOP10 regions according to values of $x_{2}$} & \multicolumn{4}{|c|}{ TOP10 regions according to values of $x_{3}$} \\
\hline No. & Region & Country & $x_{2}$ & No. & Region & Country & $x_{3}$ \\
\hline 1 & CZ01 - Praha & The Czech Republic & 8.6 & 1 & CZ01 - Praha & The Czech Republic & 59.1 \\
\hline 2 & SK01 - Bratislavský kraj & Slovakia & 7.9 & 2 & HU10 - Közép-Magyarország & Hungary & 56.6 \\
\hline 3 & EE00-Eesti & Estonia & 7.6 & 3 & SK01 - Bratislavský & Slovakia & 44.3 \\
\hline 4 & SI02-Zahodna & Slovenia & 6.5 & 4 & SI02-Zahodna & \begin{tabular}{|l|} 
Slovenia \\
\end{tabular} & 43.8 \\
\hline 5 & HU10 - Közép-Magyarország & Hungary & 5.7 & 5 & CZ06-Jihovýchod & The Czech Republic & 43.1 \\
\hline 6 & PL12 - Mazowieckie & Poland & 5.2 & 6 & HU31 - Észak-Magyarország & \begin{tabular}{|l|} 
Hungary \\
\end{tabular} & 42.9 \\
\hline 7 & LT00-Lietuva & Lithuania & 5.1 & 7 & PL12-Mazowieckie & Poland & 41.5 \\
\hline 8 & LV00 - Latvija & Latvia & 4.8 & 8 & CZ02-Strední Cechy & The Czech Republic & 37.6 \\
\hline 9 & CZ02 - Strední Cechy & The Czech Republic & 4.8 & 9 & PL51 - Dolnoslaskie & Poland & 36.3 \\
\hline 10 & PL63 - Pomorskie & Poland & 4.8 & 10 & PL63 - Pomorskie & Poland & 36.0 \\
\hline
\end{tabular}

Evaluated by the authors according to Eurostat data (2015)

With the number of patents, the situation was different. Correlation coefficients revealed that the relations between all input indicators and $y_{2}$ were weaker (Table II).

Correlation rate between a number of patents implemented $\left(y_{2}\right)$ and human capital employed $\left(x_{3}\right)$ in high technology and knowledge-intensive sectors was not significant enough at 0.01 level of confidence (2-tailed). As a result, GDP per capita $\left(y_{1}\right)$ was selected as an output indicator for the further analysis.

The number of patents was indicated as an indicator not reliable enough for the further analysis. This indicator did not significantly correlate with GDP per capita, which was supposed to be the main indicator of overall economic output. In other studies made by Bosco and Brugnoli (2010), similar conclusions were made while using a number of patents as an output indicator in the model. The calculation techniques for this indicator differ among countries and due to this fact the results remain unreliable for the analysis of different countries.

\section{Innovation System Efficiency in the Regions of Central and Eastern European Union}

At the beginning of the research, regions were ranked according to the input and output indicators. The highest values of almost all indicators tended to be in the capital regions - in Slovakia capital region Bratislavský (SK01), the Czech Republic - Praha region (CZ01), Hungary - Közép-Magyarország re- gion (HU10), Slovenia - Zahodna (SI02), Poland-Mazowieckie (PL12), Baltic States: Estonia (EE00), Lithuania (LT00) and Latvia (LV00). Higher values of all indicators tended to be in capital regions of Central EU than in the Eastern part of EU and Baltic States. All Baltic countries were between the highest values with $x_{2}$ indicator, i.e. they had high values of human resources in science and technology. One of the Baltic States - Estonia (EE00) was between the leading regions with $x_{1}$ indicator - cumulative intramural investments in R\&D. No one of Baltic States was between the leaders with $\mathrm{x}_{3}$ indicators, as in these countries not a lot of human capital was employed in high technology and knowledge-intensive sectors compared to other regions. Praha region (CZ01) and Bratislavský region (SK01) tended to be the leaders in all the indicators.

The ranking of the regional indicators revealed how many resources regions had and which regions were the leading with the input indicators. But it is necessary not only to have a lot of resources, but also to use them in an efficient way and to create the maximum output. The main idea of the efficiency analysis was to evaluate how much output regions made with current resources and to state if they used the resources in an efficient way to create a visible output in the economy.

According to the results of data envelopment analysis, 7 efficient regions were indicated out of 40 regions in Central and Eastern Europe. The average efficiency score of all the regions analysed was 0.818 . This score means that if available resources were used more intensively it would be possible to reach about 
$18.2 \%$ higher output. Therefore, in inefficient regions more attention should be devoted to how to generate higher output with current resources, how to make human capital in science and technology and R\&D investments to create and better commercialise products for a market.

Among the efficient regions (with efficiency score $\lambda_{i}=1$ ) the highest output was in SK01 - Bratislavský region (Fig. 1). This region was the leader both in an economic output $\left(y_{1}\right)$ and in the efficiency score. Other capital regions did not reach such good results. In most of the capital regions with high GDP per capita ratio, such as CZ01 - Praha, HU10 - Közép-Magyarország, PL12 - Mazowieckie, SI02 - Zahodna, higher GDP ratio could be reached with current resources. These regions were considered to be inefficient as they had a lot of input indicators but they were comparatively not efficient enough in generating real output to the regional economy compared to other regions. Bratislavský region was considered a peer region and an example for other capital regions.

Regions, such as PL41 - Wielkopolskie, SK02 - Západné Slovensko, CZ04 - Severozápad, were considered to be efficient, even though they had comparatively lower GDP per capita ratio. These regions with low input indicators generated comparatively high economic results. To enhance economic growth in these regions, more investments in science and technology could be made.

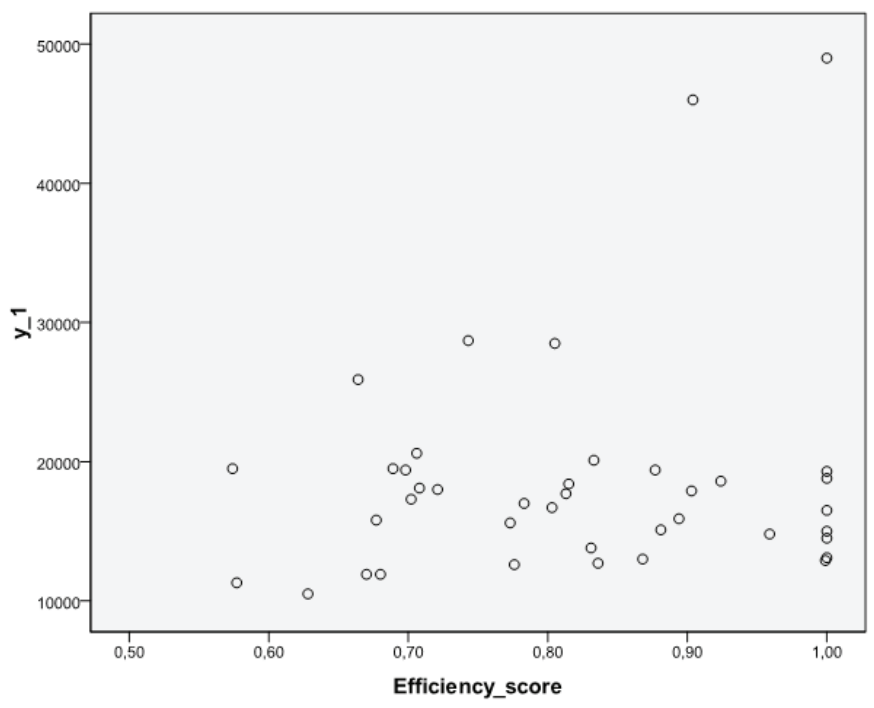

Fig. 1. The relationship between efficiency score $(\lambda)$ and GDP per capita in PPP $\left(\mathrm{y}_{1}\right), 2013$. Evaluated by the authors according to the data of Eurostat (2015).

TABLE IV

Central and Eastern EU NUTS2 Regions with Highest and Lowest Efficiency Scores $\left(\lambda_{i}\right)$ Applying Data Envelopment Analysis (DEA)

\begin{tabular}{|c|c|c|c|c|c|c|c|}
\hline \multicolumn{4}{|c|}{ TOP10 most efficient regions } & \multicolumn{4}{|c|}{ TOP10 least efficient regions } \\
\hline No. & Region & Country & $\begin{array}{l}\text { Efficiency } \\
\text { score }\left(\lambda_{i}\right)\end{array}$ & No. & Region & Country & $\begin{array}{l}\text { Efficiency } \\
\text { score }\left(\lambda_{i}\right)\end{array}$ \\
\hline 1 & SK01 - Bratislavský & Slovakia & 1 & 30 & CZ06-Jihovýchod & The Czech Republic & 0.706 \\
\hline 2 & PL41 - Wielkopolskie & Poland & 1 & 31 & PL63 - Pomorskie & Poland & 0.702 \\
\hline 3 & SK02 - Západné Slovensko & Slovakia & 1 & 32 & LT00 - Lietuva & Lithuania & 0.698 \\
\hline 4 & CZ04-Severozápad & The Czech Republic & 1 & 33 & CZ02-Strední Cechy & The Czech Republic & 0.689 \\
\hline 5 & PL43 - Lubuskie & Poland & 1 & 34 & HU23 - Dél-Dunántúl & Hungary & 0.68 \\
\hline 6 & PL52-Opolskie & Poland & 1 & 35 & PL21-Malopolskie & \begin{tabular}{|l|} 
Poland \\
\end{tabular} & 0.677 \\
\hline 7 & PL33-Swietokrzyskie & Poland & 1 & 36 & HU33 - Dél-Alföld & \begin{tabular}{|l|} 
Hungary \\
\end{tabular} & 0.67 \\
\hline 8 & PL62 - Warminsko-Mazurskie & Poland & 0.999 & 37 & SI02 - Zahodna Slovenija & Slovenia & 0.664 \\
\hline 9 & PL61 - Kujawsko-Pomorskie & Poland & 0.959 & 38 & HU31 - Észak-Magyarország & Hungary & 0.628 \\
\hline 10 & PL22 - Slaskie & Poland & 0.924 & 39 & HU32 - Észak-Alföld & \begin{tabular}{|l|} 
Hungary \\
\end{tabular} & 0.577 \\
\hline 11 & CZ01 - Praha & The Czech Republic & 0.904 & 40 & EE00-Eesti & Estonia & 0.574 \\
\hline
\end{tabular}

Evaluated by the authors according to Eurostat data (2015)

Estonia tended to be the most inefficient region with efficiency score $\lambda_{i}=0.574$. According to the efficiency score with the same level of inputs, this country could potentially generate about $40 \%$ higher economic output. The main reason for that was that Estonia had a very high rate of the intramural cumulative expenditures on research and development in purchasing power standard per inhabitant compared to other regions. More attention from policy side should be devoted to getting the most from the money spent on $R \& D$, as these expenditures do not show efficient results for the economy as a whole.

The variance of efficiency score among Polish regions was the highest. This revealed high regional efficiency disparities among Polish regions. The regional efficiency was not constant in all country's regions. Therefore, there is potential to spread good practices from one region to another, try to find a higher level of cooperation between different territories.

Baltic countries were evaluated as the least efficient regions. Estonia stood out with high rates of intramural cumulative expenditures on R\&D from other countries. But the common tendencies for the Baltic States were that they had comparatively high levels of human capital with tertiary education, but this did not generate significantly higher GDP per capita. More programmes in these countries should be made to solve the problem - how to enforce human capital with tertiary education and in science and technology to create more output with higher value added to the regional economy.

To sum up, the analysis revealed different levels of innovation system efficiency in the Central and Eastern EU regions. These 
efficiency scores indicated imbalances between available regional inputs and real output. This means that even though regions spend a lot on R\&D and have a lot of human capital with tertiary education and working in science and technology it does not guarantee that innovative products with higher value added will be created and commercialised in the economy. This type of analysis shows the results of innovation system efficiency and could be used for the formation of more precise and problem oriented regional innovation strategies.

\section{Conclusion}

Regional innovation system is one of the most important territorial components needed to generate a higher value added in the economy. Regional innovation systems differ between different territories as they have a different level of available resources for a value creation. The most important factors are related to human resources, their abilities to improve and innovate, commercialise the products created and make the most of limited public and private investments.

In the recent research, more emphasis has been placed on efficiency of regional innovation systems, as it is not only important for regions to have a lot of skilled and creative human resources or high level of investments in research and technology, but it is important to generate from these resources feasible outputs that could contribute to the economy as a whole.

This paper revealed the differences of the regional innovation system efficiency in Eastern and Central EU from the point of view of innovative resource impact on the economy as a whole. Out of 40 regions involved in the analysis, 7 regions tended to be efficient. Only one region from efficient ones was a capital region of Slovakia - Bratislavský (SK01). Other capital regions did not reach such a level of efficiency as Bratislavský region even though they had a comparatively high level of input, so Bratislavský region could serve as an example for other regions in the group by making the most result for the economy with available innovative resources.

Average efficiency score of 0.818 revealed that by improving regional performance there was a possibility to enlarge GDP per capita by about $18 \%$ without changing the level of current resources. The least technically efficient region was Estonia (EE00) followed by other Baltic States. For the Estonian case, the results were influenced by comparatively high levels of intramural cumulative investments on $\mathrm{R} \& \mathrm{D}$ that according to the calculation could give higher returns for the regional economy. According to the model with such a level of human capital with tertiary education or/and working in science and technology, all Baltic States could reach much higher level of GDP. Thus, on the one hand, the evaluation revealed inefficiency of the Baltic States; on the other, it indicated the problem and the direction for improvement of innovation strategies that should enforce human capital to create and commercialise more products to the economy.

The main restriction of this evaluation was that results could differ according to the choice of input and output indicators.

\section{REFERENCES}

Andersson, G. (2013). Rethinking Regional Innovation. Systemic Practice and Action Research. 26(1), 99-110. http://dx.doi.org/10.1007/s11213-012-9265-5

Asheim B. T., Gertler M. S. (2005). The geography of innovation: regional innovation systems. The Oxford handbook of innovation. Oxford University Press, Oxford, pp. 291-317.

Autant-Bernard C., LeSage J. P. (2011). Quantifying knowledge spillovers using spatial econometric models. Journal of Regional Science, 5(3), 471-496. http://dx.doi.org/10.1111/j.1467-9787.2010.00705.x

Bai, J. (2013). On Regional Innovation Efficiency: Evidence from Panel Data of China's Different Provinces, Regional Studies, 47(5), 773-788. http://dx.doi. org/10.1080/00343404.2011.591784

Bosco, M., G., Brugnoli, A. (2010). Regional Efficiency, Innovation and Productivity. RSA Conference proceedings, Pecs.

Broekel, T. (2012). Collaboration Intensity and Regional Innovation Efficiency in Germany - A Conditional Efficiency Approach. Industry and Innovation, 19(2), 155-179. http://dx.doi.org/10.1080/13662716.2012.650884

Broekel, T., Buerger, M., Brenner, T. (2010). An investigation of the relation between cooperationand the innovative success of German regions. Papers in Evolutionary Economic Geography.10.11, Utrecht University.

Burda, M. C., Severgnini, B. (2009). TFP Growth in Old and New Europe. Comparative Economic Studies, 51(4), 447-466. http://dx.doi.org/10.1057/ ces.2009.19

Cai, Y., Hanley, A. (2014). Innovation rankings: good, bad or revealing? Applied Economics Letters. 21(5), 325-328. http://dx.doi.org/10.1080/135048 $\underline{51.2013 .859366}$

Chen, K., Guan, J. (2012). Measuring the Efficiency of China's Regional Innovation Systems: Application of Network Data Envelopment Analysis (DEA), Regional Studies, 46(3), 355-377. http://dx.doi.org/10.1080/00343 404.2010.497479

Cooke, P. (1992). Regional innovation systems: competitive regulation in the new Europe. Geoforum, 23(3), 365-382. http://dx.doi.org/10.1016/00167185(92)90048-9

Cooke, P. (2004). The regional innovation system in Wales: evolution or eclipse. In Cooke P, Heidenreich M, Braczyk H. (Eds) Regional innovation systems, 2nd Edition. Routledge, London and New York, pp. 214-233.

D'Agostino, L. M., Laursen, K., Santangelo, G. D. (2013). The impact of R\&D offshoring on the home knowledge production of OECD investing regions. Economic Geography, 13(1), 145-175. http://dx.doi.org/10.1093/jeg/lbs012

Daraio, A., Simar, L. (2007). Nonparametric efficiency analysis: a multivariate conditional quantile approach. Journal of Econometrics, 140(2), 375-400. http://dx.doi.org/10.1016/i.jeconom.2006.07.002

De Bruijn, P., Lagendijk, A. (2005). Regional innovation systems in the Lisbon strategy. European Planning Studies, 13(8), 1153-1172. http://dx.doi. org/10.1080/09654310500336519

Doloreux, D. (2003) Regional innovation systems in the periphery: the case of the Beauce in Quebec (Canada). International Journal of Innovation Management. 7(1), 67-94. http://dx.doi.org/10.1142/S1363919603000738

Drăgan, N., Dzemyda, I., Karčiauskas, A. (2011). An approach to evaluate influence of European Union innovation policy to increase the economic equality between member states. Intellectual economics: scientific research journal, 1(9), 23-36.

Dzemyda, I., Karčiauskas, A. (2012a). Inovacijų sistemos ir universitetai: teoriniai aspektai. Social sciences studies: research papers, 4(3), 991-1007.

Dzemyda, I., Karčiauskas, A. (2012b). Inovaciju sistemos ir aukštojo mokslo saveikos analizè. Applied economics: systematic research. 6(1), 41-59.

Dzemydaite, G., Galinienė, B. (2013). Evaluation of regional efficiency disparities using efficient frontier analysis. Ekonomika, 92(4).

Dzemydaite, G., Dzemyda, I., Galinienè, B. (2015). The Evaluation of Regional Innovation Systems' Efficiency in New Member States of European Union. Journal of Applied Sciences, Vol. X, Issue 3(33), p. 317-328.

Kaihua C., Mingting, K. (2014). Staged efficiency and its determinants of regional innovation systems: a two-step analytical procedure. The Annals of Regional Science. 52(2), 627-657, http://dx.doi.org/10.1007/s00168-014-0604-6

Lafarga, C. V., Baderrama. J. (2015). Efficiency of Mexico's regional innovation systems: an evaluation applying data envelopment analysis (DEA). African Journal of Science, Technology, Innovation and Development. 7(1). http:// dx.doi.org/10.1080/20421338.2014.979652

Makkonen, T.\& T. Inkinen (2014). Spatial scaling of regional strategic programmes in Finland: A qualitative study of clusters and innovation systems. Norsk Geografisk Tidsskrift-Norwegian Journal of Geography, 68(4), 216-227. http://dx.doi.org/10.1080/00291951.2014.924551

Moodysson, J., Zukauskaite, E. (2014). Institutional Conditions and Innovation Systems: On the Impact of Regional Policy on Firms in Different Sectors. Regional Studies, 48(1), 127-138. http://dx.doi.org/10.1080/0034340 4.2011.649004

ESPON (2012). Factsheet Latvia - Lithuania. ESPON Project TERREVI.

European Commission (2004). Commission Communacation. Third report on economic and social cohesion. COM(2004) 107 final. Brussels, 18.2.2004.

European Commission (2014). Innovation Union Scoreboard 2014. Retrieved from http://ec.europa.eu/enterprise/policies/innovation/files/ius/ius-2014 en.pdf accesed on 10102014. 
European Commission (2013). EU Cohesion Policy 2014-2020: legislative proposals. Retrieved from http://ec.europa.eu/regional_policy/what/future/ proposals 20142020 en.cfm accessed on 10092015.

Eurostat (2015). Database by themes - General and regional statistics. Retrieved from http://ec.europa.eu/regional_policy/what/future/proposals_2014_2020_en.cfm accesed on $1509201 \overline{4}$.

Fritsch, M., Slavtchev, V. (2011). Determinants of the Efficiency of Regional Innovation Systems. Regional Studies, 45(7), 905-918, http://dx.doi. org/10.1080/00343400802251494

Howells, J. (2012). The geography of knowledge: never so close but never so far apart. Journal of Economic Geography, 12(5), 1003-1020, http://dx.doi. org/10.1093/jeg/lbs027

Svetikas, K. Z., Dzemyda, I. (2009). An approach to the evaluation of regional inequalities: a case study of Lithuanian counties. Intellectual economics. 2(6), 96-107.

Tharakan J. (2015). Indigenous knowledge systems - a rich appropriate technology resource. African Journal of Science, Technology, Innovation and Development, 7(1), 52-57, http://dx.doi.org/10.1080/20421338.2014.987987

Yi, S., Fengyan, C. (2015). Regional Innovation Systems Based on Stochastic Frontier Analysis: A Study on Thirty-One Provinces in China. Science, Technology\&Society, 20(2), 204-224. http://dx.doi. org/10.1177/0971721815579808

Zhong, W., Yuan, W., Li, X. S., Huang, Z. (2011). The performance evaluation of regional R\&D investments in China: An application of DEA based on the first official China economic census data. Omega, 39(4), 447-455. http:// dx.doi.org/10.1016/j.omega.2010.09.004

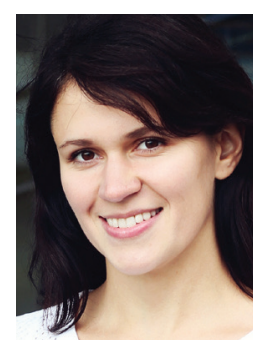

Giedrè Dzemydaite is a $\mathrm{PhD}$ candidate in the field of economics (04S) and Lecturer at Vilnius University, the Faculty of Economics, the Department of Economic Policy, Lithuania. Her main fields of scientific interest are regional economics, economic policy and measures of efficiency.

Address: Saulètekio al. 9, LT-10222 Vilnius, Lithuania.

E-mail: giedre.dzemydaite@ef.vu.1t

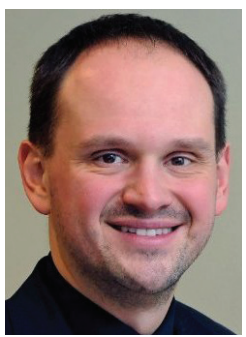

Ignas Dzemyda is an Associate Professor at Vilnius Gediminas Technical University, the Faculty of Management, Lithuania (03S). His main fields of scientific interest are strategic management and planning, international economics and policy.

Address: Saulètekio al. 11, LT-10223 Vilnius, Lithuania.

E-mail: ignas.dzemyda@vgtu.lt

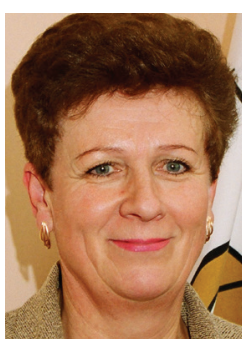

Birutė Galinienė is a Professor at Vilnius University, the Faculty of Economics, the Department of Economic Policy, Lithuania.

She is a board member of the Lithuanian Association of Property Evaluation. She is a member of editorial board of scientific journals of Vilnius University "Ekonomika" and "Transformation of Business and Economics" and of Vilnius Gediminas Technical University "International Journal of Strategic Property Management".

Research interests: problems related to the improvement of management and valuation system of real estate and business. She is the author of about 160 scientific articles.

Address: Saulètekio al. 9, LT-10222 Vilnius, Lithuania.

E-mail: birute.galiniene@ef.vu.lt 